\title{
Fire Management Preparedness at PT X Sleman Regency
}

\author{
Azham Umar Abidin ${ }^{1,2, *}$, Suryadi Sepriawan ${ }^{1}$, Any Juliani ${ }^{1}$, and Nur Aini Iswati Hasanah ${ }^{1}$ \\ ${ }^{1}$ Department of Environmental Engineering, Occupational Safety and Health, Universitas Islam \\ Indonesia, Yogyakarta 55584, Indonesia \\ ${ }^{2}$ Centre for Occupational Health Safety \& Environmental, Faculty of Civil Engineering and Planning, \\ Universitas Islam Indonesia
}

\begin{abstract}
The implementation of Occupational Safety and Health (OSH) is one of the efforts to create a workplace that is safe, healthy, and free from environmental pollution, to minimize work accidents and occupational diseases, and to finally improve work efficiency and productivity. The mortality rate caused by fire cases in the industrial sector are high. Therefore, fire management is needed as the implementation of Occupational Safety and Health. This study aims to determine management preparedness in dealing with fire emergencies to prevent fire and minimize the potential hazard risk of PT X. The method in this study uses qualitative methods with triangulation approach through in-depth interview, observation, checklist form and documentation. The research results through in-depth interviews show that fire management is still not optimal, i.e. there are no hydrants, automatic alarms and emergency doors. In addition, the fire prevention unit has been established but not specifically. From the observation of using the checklist form, it showed that fire management has 3 Good (G) categories, includes fire extiguisher (82\%), standard operating procedures $(100 \%)$, and evacuation routes $(100 \%)$. The others are 5 Less (L) categories, includes hydrant $(0 \%)$, alarm $(0 \%)$, emergency door $(0 \%)$, education and emergency response training $(33 \%)$, fire management unit $(25 \%)$.
\end{abstract}

\section{Introduction}

The implementation of Occupational Safety and Health (OSH) is one form of efforts to create a workplace that is safe, healthy, and free from environmental pollution, so as to decrease workplace accidents and occupational diseases, in the end it can enhance work efficiency and productiveness. Based on data from the International Labour Organization (ILO) in 2012, cases of fires in the industrial sector in the world resulted in 426 deaths, these results indicated that there is high mortality rate caused by fire cases in the industrial sector. Most of the victims that died are $67.8 \%$ of the garment company sector [1].

Fires incidents in the work environment will have a huge impact on employers, labour, society and the environment. Many aspects arise when a fire occurs such as material loss,

* Corresponding author: azham.abidin@uii.ac.id 
company stability, environmental damage, loss of workers' life or the community around the company. The cases of fire incidents in Indonesia actually often result in loss of assets or other, one example of a fire in the company is PT Madom Cikarang, Bekasi. Those incident was as a result of a spark on one of the engines, then because of a gas leak, there was a big fire [2]. Therefore, availability of good safety building facility and fire preparedness in Indonesian company could be an effort to protect the workers/employees and the company's valuable assets. It can minimize the risk of loss in the event of an emergency such as fire, earthquake or other emergency conditions [3].

PT $\mathrm{X}$ is a national private company in Indonesia that engaged in manufacturing of hospital equipment products with domestic and export markets. It is classified as a company with moderate risk of fire hazard. From the results of preliminary observations carried out directly covering the facilities and infrastructure, it has a light fire extinguisher, but there are no hydrants, automatic alarms and emergency doors. Fire preparedness as the implementation of OSH in PT X need to be check. This study also aims to determine the management of preparedness in dealing with fire emergencies to prevent fire and minimize the potential hazard risk in PT X.

\section{Methods}

\subsection{Research Design}

This research uses qualitative method with triangulation approach through in-depth interview, observation, checklist form, documentation, and data using primary and secondary data. This research was conducted in April-June 2017.

The respondent's in-depth interview consisted of company management, Environmental Health and Safety (EHS), and emergency response team with 3 subjects. In-depth interviews include Standard Operating Procedure (SOP) for fire management, medical emergency procedures, post-evacuation procedures, stakeholder/outside party coordination procedures. It also include interview about the condition of fire management in PT X, fire prevention efforts, fire simulation, training, fire prevention units/teams, fire prevention facilities and infrastructure, facilities and infrastructure maintenance functions.

There are 8 parameters of the checklist form used for emergency preparedness, i.e., fire emergency response units, fire emergency response organizations, maintenance of active fire protection facilities, Standard Operating Procedures (SOP), and fire emergency response exercises. Those parameters referring to Minister of Manpower Regulation No.4/MEN/1980 is concern about facilities for light fire extinguishers [4], Ministerial Regulation No.2/1983 is concern about automatic fire alarm installation [5], Minister of Public Works Regulation No.26/PU/2008 is concern about hydrant elements, evacuation routes [6], SNI 03-1746-2000 is concern about emergency doors [7], Ministerial Decree No.11/MEN/2000 is concern about emergency response SOP elements, education and emergency response trainning [8], and Ministerial Decree No.186/MEN/1999 is concern about elements of fire prevention units [9]. Parameter scoring value follow Table 1.

Table 1. Parameters Scoring Level

\begin{tabular}{|l|l|l|}
\hline \multicolumn{1}{|c|}{ Score } & \multicolumn{1}{c|}{ Suitability } & \multicolumn{1}{c|}{ Reliability } \\
\hline$>80-100$ & According to requirements & Good (G) \\
\hline $60-80$ & $\begin{array}{l}\text { Installed but there are a small part of installations that do } \\
\text { not meet the requirements }\end{array}$ & Enough (E) \\
\hline$<60$ & not in accordance & Less (L) \\
\hline
\end{tabular}




\section{Results and Discussion}

The results of in-depth interviews show that the management of PT X's fire management is still not maximal. It can be seen in Table 2 .

Table 2. Suitability Parameters

\begin{tabular}{|l|l|c|c|c|}
\hline \multirow{2}{*}{ No } & \multirow{2}{*}{ Variable Type } & \multicolumn{2}{c|}{$\begin{array}{c}\text { Comparison of Suitability } \\
\text { Parameters }\end{array}$} & Total \\
\cline { 3 - 5 } & & Suitable & Not suitable & \\
\hline 1 & Light Fire Extinguishers & 9 & 2 & 11 \\
\hline 2 & Alarm & 0 & 11 & 11 \\
\hline 3 & Hydrant & 0 & 6 & 6 \\
\hline 4 & Evacuation route & 5 & 0 & 5 \\
\hline 5 & Emergency door & 0 & 4 & 6 \\
\hline 6 & $\begin{array}{l}\text { Education \& Emergency } \\
\text { Response Training }\end{array}$ & 2 & 4 & 4 \\
\hline 7 & $\begin{array}{l}\text { Standard Operating } \\
\text { Procedure }\end{array}$ & 4 & 0 & 4 \\
\hline 8 & Fire Management Unit & 1 & 3 & $51(100 \%)$ \\
\hline
\end{tabular}

The company already has a Standard Operating Procedure (SOP) related to fire prevention. The SOP relate specifically to medical emergencies, post evacuations, and coordination when the fire occurs. As well as the direct practice during fire simulation. Regarding infrastructure facilities is quite good such as the placement of Light Fire Extinguishers at points prone to fire, adding gas detectors to areas that have the potential to cause gas leakage and also the facilities are still running well because of regular monitoring, but there are no hydrants, automatic alarms and emergency doors. In terms of education and training in dealing with fires, the company has already done so and the fire management unit has been established but not specifically. From the observations using a checklist form consisting of 8 parameters regarding the preparedness of fire management in PT X using scoring (Table 2) shows that the company gets $41 \%$ of the suitability of the regulatory references used.

In anticipation of disaster management such as fires, earthquakes or other, structured and appropriate steps must be prepared to protect employees, and the company's valuable assets as an effort to minimize the risk of damages caused [3]. Parameters used to visualise the preparedness of fire management are in terms of fire emergency response procedures, fire prevention units, facilities and infrastructure, and education and emergency response training. The results of research at PT X regarding the parameters of facilities and infrastructure from the side of the Light Fire Extinguisher as a whole has been good, but there is still a shortage of automatic fire alarm and emergency doors. Routine inspections and maintenance of fire facilities need to be carried out, if there are non-conformities, the Environmental Health Safety section and input materials for internal audit are immediately reported.

\section{1 Fire Facilities and Infrastructure}

Based on fire infrastructure and facilities At PT X, it has about 200 Light Fire Extinguishers located throughout the production section, offices, showrooms and workshops which consist of three types of Light Fire Extinguishers, i.e. halon, dry chemical powder, and $\mathrm{CO}_{2}$. In terms of maintenance of Light Fire Extinguishers, it's checked once 
every month. However, there are still some light fire extinguishers that are blocked by manufactured goods, which may cause a light fire extinguisher not to be reached if there is a fire. The results of the analysis of data are obtained from 11 categories, 9 categories meet the requirements, including 6 months inspection regarding the contents of the tube, the outside of the tube is not defective, the transmitter funnel should not be defective, 12 months inspection, regarding the contents of the tube, the discharge pipe, the inside is not perforated, dry chemical headgear is not damaged, and pressure must be adequately filled. Out of all that, 2 parameters are not met, i.e. not weighing the weight of $\mathrm{CO}_{2}$ and chemical powder fire extinguishers, the fire extinguisher as a means of fire emergency response in PT X scores $82 \%$ and is in a Good category (G). In a sugar production company, installation of adequate light fire extinguishers are in the workplace as an effort to protect fires, it requires less or more effective costs to prevent than the amount of losses incurred when a fire occurs [10]. The textile industry, result of 44 Light Fire Extinguishers was found in the company's area. The level of conformity is $50.2 \%$ and the level of nonconformity is $49.8 \%$. Incompatibility of Light Fire Extinguishers in the company, i.e. the position, placemark, height and distance between the Light Fire Extinguisher is not according to the standards set. This will hamper when a real fire occurs [11].

Based on observations regarding fire alarms, the provision of detection and alarm systems must use automatic alarms [6], while PT X still uses manual alarms. In the fire siren section it still cannot be heard especially in the production section. So the siren still can't be heard clearly. For manual fire alarm placement, there are several points in the building, namely: (1) the painting room has 2 points, (2) the Assembling production room has 1 point. (3) office space is 1 point, (4) packing room has 1 point. Based on the analysis in PT X, no one met the requirements because the company still uses manual alarms, then automatic alarms as a means of fire emergency response in PT X companies get a value of $0 \%$ and belong to the category of Less (L). The fertilizer industry in factories $1 \mathrm{~A}$ and $1 \mathrm{~B}$, that factories $1 \mathrm{~A}$ and $1 \mathrm{~B}$ have automatic alarm installations with a score of $95 \%$, installation of lighting, direction signs and hazard warning systems by $83 \%$ [12]. This is a form of effort in which the fire alarm is good and in the event of an emergency the workers know by hearing the alarm, so that workers can evacuate themselves to the assembly point. Study of the effectiveness of a fire system, one of which is a system alarm. System alarms have an effective value of between $86 \%-97 \%$, the results are in good category and generally consistent with the data that has been in the literature and previous research [13].

From the results of observations regarding hydrants and emergency doors, PT X does not have a hydrant and emergency door. The building that has a total floor area of approximately more than $500 \mathrm{~m}^{2}$ must have a hydrant [6]. PT X has not fulfilled the requirements because the company does not have a hydrant and an emergency door as a means of fire emergency response, in order to get a value of $0 \%$ and belongs to the Less (L) category. The emergency door. get 60 scores, have not been optimal. It also does not have fireproof construction, fire-resistant doors and windows. Based on the results of the indepth interview at PT X, the emergency door infrastructure had already been installed, but due to the factory widening renovation up till now, the emergency door cannot be replaced. This is a statement for future improvement. As for the evacuation route, the company already has the infrastructure with provisions including easy-to-read direction indicators, easy-to-see colour usage and contrast, there is an "EXIT" line sign [14]. In this respect, the company gets a score of $100 \%$ and belongs to the Good $(\mathrm{G})$ category. The fertilizer industry regarding the application of hydrants was $62 \%$, the results were not optimal if there was a fire. The hydrant is one of the most critical facilities if a fire occurs, because if you use a light fire extinguisher it still cannot be controlled, then the next step is using the hydrant because the fire coverage has increased. As we know, there is a waiting time for fire truck to arrive at the location, so the fires are more widespread [12]. 


\subsection{Emergency Response Procedures/Standard Operational Procedures}

Emergency response procedures are one of the parameters in fire management that aim to fire prevention. The company already has an emergency response procedure. Data analysis was conducted using 4 parameters, i.e. the completeness related to the initial notification if fire occurs, improving procedures, future conditions adjustment, and coordinate with the fire department. From these results, the company gets a value of $100 \%$ and belongs to the Good (G) category.

Procedures for emergency situations are one way to prevent fires and are more effective when applied rather than making an effort when a fire occurs [10]. The company established an organizational team and had carried out a fire management program according to the procedures that had been made. With the aim of carrying out the stages when an emergency occurs in accordance with the procedures that have been established [15].

\subsection{Fire Management Unit}

PT X is classified with the level of risk of building fire, including the type of moderate risk of fire hazard. Workplaces have a high amount and ease of burning in the event of a fire releasing high heat, so that the fire can spread quickly. In accordance with the ratio of the minimum number of classifications, qualifications and competencies of fire prevention personnel in the workplace [9].

PT X already has a fire prevention unit. But, there is no competence of each personnel and it doesn't have Occupational Safety and Health Expert, specifically a fire specialist. The results of data analysis during observations from 4 categories included fire role officers, firefighters, firefighting unit coordinators and fire specialist Occupational Safety and Health experts, 1 category that fulfilled the requirements is fire role officer. The fire prevention unit in the PT X company got a value of $25 \%$ and are included in the category of Less (L). In addition, training is also carried out regularly to the team to get used to emergency situations. The company already has a fire role officer with 100 scores, a fire prevention team with 92 scores, and a fire prevention team coordinator with 85 scores. It is necessary for the team responsible for a fire in the company, and early preparation for fire prevention efforts [14].

\subsection{Emergency Response Education and Training}

Emergency Response Education and Training parameters, concerning personnel training [8], there are 6 criteria and 2 criteria have been met. Results of 4 criteria have not been fulfilled, i.e. no specific division regarding team division, there has been no meeting for 3 months to discuss issues that include the readiness of all members, not yet held 6 months fire rescue exercises and not coordinating with relevant stakeholders regarding communication if a fire occurs. Based on the analysis obtained in companies from 6 categories, 2 categories meet the requirements, the fire management unit in the company gets a value of $33 \%$ and belongs to the category of Less (L). Education and emergency response training are vital in fire management. This aspect is beneficial in the fire prevention stage, one of the efforts to prevent the occurrence of fire are through education and training to train and familiarize emergency response team personnel in all emergency situations that occur. The management policies have conducted fire simulations, set regulations for fire control, and education and training are regularly given to employees 2 to 3 times a year as an effort to minimize the risk of fire [16]. The education and training is 
early anticipation for fire prevention efforts and fewer costs incurred, if there is an actual fire in the company [10].

\section{Conclusion}

The management of fire in PT X is still not optimal, based on the results of research through in-depth interviews and observations shows that fire management has 3 categories Good $(\mathrm{G})$ includes a light fire extinguisher with a value of $82 \%$, an evacuation route with a value of $100 \%$, SOP with a value of $100 \%$. While the 5 categories of Less (L) include hydrant with $0 \%$ value, alarm with $0 \%$ value, Emergency door with $0 \%$ value, Education and emergency response training with a value of $33 \%$, Fire Management Unit with a value of $25 \%$. From these results indicate that PT X needs to make improvements in facilities and infrastructures that have not been fulfilled such as hydrants, automatic alarms, routine maintenance and placement of light fire extinguishers, in order not to obstruct by goods, besides firefighting units need occupational safety and health expert on fire specialists and education and training need to be optimized. This is an effort to reduce the risk of fire in the workplace.

\section{References}

1. ILO, (2012)

2. Fadli, (2015)

3. A.U. Abidin, F.R. Putranto, J. Medika Respati 12, 4 (2017).

4. Kementerian Tenaga Kerja dan Transmigrasi Republik Indonesia, Peraturan Menteri Tenaga Kerja dan Transmigrasi No./MEN/04/1980 Tentang Syarat-syarat dan Pemeliharaan Alat Pemadam Api Ringan (APAR) (Kemenakertrans, Jakarta, 1980).

5. Kementerian Tenaga Kerja dan Transmigrasi Republik Indonesia, Peraturan Menteri Tenaga Kerja dan Transmigrasi No.02/1983 Tentang Instalasi Alarm Kebakaran Otomatik (Kemenakertrans, Jakarta, 1983).

6. Kementerian Pekerjaan Umum Republik Indonesia, Peraturan Menteri Pekerjaan Umum No. 26/PRT/M/2008 Tentang Persyaratan Teknis Sistem Proteksi Kebakaran Pada Bangunan Gedung dan Lingkungan (KemenPU, Jakarta, 2008).

7. Badan Standarisasi Nasional, SNI 03-1746-2000. Tata Cara Perencanaan dan Pemasangan Sarana Jalan Keluar Untuk Penyelamatan Terhadap Bahaya Kebakaran Pada Bangunan Gedung (BSN, Jakarta, 2000).

8. Kementerian Negara Pekerjaan Umum, Keputusan Menteri Negara Republik Indonesia No. 11/KPTS/2000 Tentang Manajemen Penanggulangan Kebakaran Bangunan Gedung (KepmenPU, Jakarta, 2000).

9. Kementerian Tenaga Kerja Republik Indonesia, Keputusan Menteri Tenaga Kerja Kep.186/MEN/1999 Tentang Unit Penanggulangan Kebakaran di Tempat Kerja (Kepmenaker, Jakarta, 1999).

10. R. Lokupure, A. Kadam, V. Nerle, IJERA 2, 4 (2012).

11. F. Lutfan, Ekawati, B. Kurniawan, J. Kesehatan Masyarakat 12, 5 (2014).

12. R. Dewi, 2012, J. Kesehatan Masyarakat 1, 2 (2012).

13. Marsh, Effectiveness of Fire Safety Systems for Use in Quantitave Risk Assessments (New Zealand Fire Service Commission, New Zealand, 2008). 
14. H.A. Ummah, Gambaran Sistem Penanggulangan Kebakaran di PT.PLN Area Pengatur Distribusi Jateng \& DIY (Fakultas Kesehatan Masyarakat Universitas Muhammadiyah Semarang, Semarang, 2016).

15. B.K. Putra, Pencegahan dan Penanggulangan Kebakaran di PT INKA (PERSERO) Madiun Jawa Timur (Program Diploma III Hiperkes dan Keselamatan Kerja Fakultas Kedokteran Universitas Sebelas Maret Surakarta, Surakarta, 2010).

16. Serani, L. Tarigan, L. Syahri, Penerapan Manajemen Risiko Kebakaran di Area Produksi PT Wilmar Bioenergi Indonesia Kawasan Industri Dumai-Pelintung Tahun 2015 (Departemen Kesalamatan dan Kesehatan Kerja FKM USU Universitas Sumatera Utara, Medan, 2015). 